\title{
Evaluation of the relationship between IL- 12 , IL-13 and TNF-a gene polymorphisms with the susceptibility to brucellosis: a case control study
}

\author{
Sima Kazemi ${ }^{1}$, Asad Vaisi-Raygani ${ }^{2}$, Fariba Keramat ${ }^{3}$, Massoud Saidijam ${ }^{4}$, Ali Reza Soltanian ${ }^{5}$,
} Mahdi Alahgholi-Hajibehzad ${ }^{6}$, Seyed Hamid Hashemi ${ }^{3}$ and Mohammad Yousef Alikhani ${ }^{1,3^{*}}$ (D)

\begin{abstract}
Background: The cytokine gene polymorphism is important for the genetic susceptibility of infectious diseases. The aim of the present study was to investigate the relationship between TNF-a, IL-12, and IL-13 gene polymorphisms and predisposition to brucellosis.

Methods: In this study, 107 patients with brucellosis and 107 healthy individuals were evaluated. The SNPs of TNF-a)- 238 $\mathrm{G} / \mathrm{A}$ ) and IL-12 (+ $1188 \mathrm{~A} / \mathrm{C}$ ) were done by amplification refractory mutation system-polymerase chain reaction (ARMS-PCR) and IL-13 genotyping at positions - 1512 (A/C) and -1112 (C/T) were analysis by restriction fragment length polymorphism-polymerase chain reaction (RFLP-PCR) methods. IL-12, IL-13 and TNF-a serum levels were measured by a sandwich enzyme-linked immunosorbent assay (ELISA).

Results: IL-13 $(-1512 \mathrm{~A} / \mathrm{C})$ was associated with Brucellosis risk in dominant model $(\mathrm{OR}(95 \% \mathrm{Cl})=2.17(1.02-$ 4.62)), P-value $=0.041$. However, there was no difference in allele and genotype frequencies of TNF-a)- 238 $\mathrm{G} / \mathrm{A}), \mathrm{IL}-12(+1188 \mathrm{~A} / \mathrm{C})$ and IL-13 [-1512 (A/C) and - $1112(\mathrm{C} / \mathrm{T})]$ between patients and controls. Serum levels of IL-12 and TNF-a were significantly more frequent in the patients than in the control groups.
\end{abstract}

Conclusions: The IL-13 gene polymorphism can be used as a biomarker for detecting susceptibility to Brucella disease.

Keywords: Cytokines, Polymorphisms, Brucellosis, Iran

\section{Background}

Brucella spp. are Gram-negative, non-spore forming, nonmotile, facultative intracellular bacteria, which cause an infectious disease called Brucellosis [1]. Transmission of these bacteria to humans through the use of unpasteurized dairy products and inhalation of contaminated aerosols with infected animal $[2,3]$. Clinical features of active brucellosis in humans included fever, sweating, weight loss, arthralgia, hepatomegaly, splenomegaly, headache, endocarditis and clinical manifestations in domestic animal in both female

\footnotetext{
* Correspondence: alikhani43@yahoo.com; alikhani@umsha.ac.ir

${ }^{1}$ Department of Microbiology, School of Medicine, Hamadan University of Medical Sciences, Hamadan, Iran

${ }^{3}$ Brucellosis Research Center, Hamadan University of Medical Sciences, Hamadan, Iran

Full list of author information is available at the end of the article
}

and males include abortion, vaginal secretions, placenta retention, low fertility rate, epididymitis, infertility, sperm abnormalities. Abortion often has symptoms of placental retention and metritis that may cause infertility [4-7]. The disease in areas like the Middle East, Eastern Europe, Africa, Latin America is endemic $[8,9]$.

Hamadan province is one of the high prevalent cities in western Iran [10]. Cytokines set the pathway for adaptive immune responses [11]. Studies have shown that reducing or increasing the expression of cytokines can play a major role in pathogenicity. Moreover, protection in this disease is carried out by T-Helper 1 cells $\left(\mathrm{Th}_{1}\right)$ while $\mathrm{T}$-Helper 2 cells $\left(\mathrm{Th}_{2}\right)$ response is effective in exacerbating the disease [12]. Upon infection, phagocytes are activated to produce 
proinflammatory cytokines including Tumor necrosis factor-a (TNF-a) and Interleukin-12 (IL-12). Interleukin 12 to produce interferon gamma, which stimulates the response of $\mathrm{Th}_{1}$ and activates macrophages. Activated macrophages can kill intracellular Brucella and eliminate the infection $[13,14]$. Similar IFN- $\gamma$, TNF-a as well as is a vital agent for the clearance of brucellosis infection from the host [15]. IL-12, is one of the inherent immune inflammatory cytokines, plays a major role in controlling infection in intracellular bacteria. This cytokine is a central cytokine in the differentiation of $\mathrm{Th}_{1}$ cells [16]. IL-13 is pivotal proinflammatory cytokines and down-regulates $\mathrm{Th}_{1}$ responses. Consequently this cytokine promotes intracellular infection [17]. Genetic variation in interleukin 12 , interlukin-13 and TNF- $\alpha$ has been studied in various diseases including mycobacterial infection, type1diabetes, periodontitis, viral diseases and autoimmune disorders [18-22]. Polymorphisms in the genes of cytokines can increase or decrease their expression and affect the determination of acute or chronic disease [23]. Since genetic variation in various populations and the presence of specific polymorphisms in patients, understanding the cytokine pattern as an important factor in the clinical outcome of brucellosis infection can be effective in controlling the disease. The aim of the present study was to investigated the association between TNF- $\alpha$ )- 238 G/A), IL-12 (+ 1188 $\mathrm{A} / \mathrm{C})$, and IL-13 (-1512 A/C and $-1112 \mathrm{C} / \mathrm{T})$ gene polymorphisms and their serum levels and susceptibility to brucellosis comparison to healthy subjects.

\section{Methods}

\section{Patients and controls}

This study was performed in the Infectious Diseases Unit at Sina Hospital of Hamadan province, Iran. Between December 2017 and June 2018. The present study included 107 patients (79 men and 28 women) with brucellosis (age range $17-78$ years and mean $\pm \mathrm{SD}=43.63 \pm 16.21)$ and 107 healthy individuals as a control group (76 men and 31 women, age range $20-60$ and mean $\pm S D=36.37 \pm 9.11$ ). Diagnosis of brucellosis was based on clinical findings, positive serological tests and positive blood cultures or PCR [24].

Inclusion criteria for healthy people included no previous contact with animals, no consumption of unpasteurized dairy products and without any clinical symptoms and exclusion criteria were any antibody to brucellosis in serological tests. Healthy individuals were chosen from the same geographical areas of the patients.

The Ethical Committee of Hamadan University of Medical Sciences evaluated and approved the investigation and written informed consent was obtained from all participants (Ethical committee ID: IR.UMSHA.REC.1396. 157).

\section{DNA isolation and cytokine genotyping}

Genomic DNA was extracted from blood samples by blood DNA extraction kit (Sina- Clon, Iran) according to the manufacturer's protocol. The IL-12 (+1188 A/C) and TNF- $\alpha(-238 \mathrm{~A} / \mathrm{G})$ genotyping was carried out by amplification refractory mutation system polymerase chain reaction method (ARMS-PCR) technique.

The primers used in the PCR reaction for IL-12 included common primer 5'ATCTTGGAGCGAATG GGC at 3', C allele primer 5'TTGTTTCAATGAGCATTTAGCATCT 3'and A allele primer 5'TTG TTTCAATGAG CATTTAGCATCG 3'. The thermocycling conditions for IL-12 included a primary denaturation step at $94{ }^{\circ} \mathrm{C}$ for 3 min followed by 35 cycles at $94^{\circ} \mathrm{C}$ for $30 \mathrm{~s}$, annealing temperatures at $65^{\circ} \mathrm{C}$ for $45 \mathrm{~s}$, extension at $72{ }^{\circ} \mathrm{C}$ for $45 \mathrm{~s}$ and a final extension step in $72^{\circ} \mathrm{C}$ for $5 \mathrm{~min}$. The PCR products for IL-12 were $784 \mathrm{bp}$.

The primers used in the PCR reaction for TNF- $\alpha$ ($238 \mathrm{~A} / \mathrm{G}$ ) included common primer 5'CCGGATCATGC TTTCAGTGC 3', G allele primer 5'AGACCCCCCT CGGAATCG 3', and A allele primer 5'AAGACCCC CCTCGGAATCA 3'. The forward and reverse primers for internal control (B2-microglobulin gene) were 5'CCAAAGATTCAGGTTTACTCACG 3', and 5'ACT'TAACTATCTTGGGCTGTGAC3' respectively with cycling conditions of $95^{\circ} \mathrm{C} 4 \mathrm{~min}$, followed by initial DNA denaturation at $95^{\circ} \mathrm{C}$ for $4 \mathrm{~min}$, then 25 cycles of denaturation at $95^{\circ} \mathrm{C}$ for $20 \mathrm{~s}$, annealing temperature for TNF- $\alpha$ (- $238 \mathrm{~A} / \mathrm{G})$ and B2-microglobulin gene at $58^{\circ} \mathrm{C}$ and $66^{\circ} \mathrm{C}$ respectively for $50 \mathrm{~s}$ and extension at $72{ }^{\circ} \mathrm{C}$ for $50 \mathrm{~s}$, followed by the final extension at $72{ }^{\circ} \mathrm{C}$ for $10 \mathrm{~min}$. The PCR products for TNF- $\alpha$ and B2-microglobulin were $590 \mathrm{bp}$ and 266 bp respectively $[25,26]$.

The IL-13 (-1512A/C) and IL-13 (-1112C/T) SNPs were analyzed by the polymerase chain reaction-restricted fragment length polymorphism (PCR-RFLP) method.

For IL-13 $(-1512 \mathrm{~A} / \mathrm{C})$, the primers were 5'CAACC GCCGCGCCAGCGCCTTCTC 3' and 5'CCGCTA CTT GGCCGTGTGACCGC 3', and the restriction enzyme was BstUI (Fermentase, Lithuania). The A allele yielded 2 bands of 216 and $29 \mathrm{bp}$ and C allele yielded 194, 29, and $22 \mathrm{bp}$ fragments. For IL-13 $(-1112 \mathrm{C} / \mathrm{T})$, the primers were 5'GGAATCCAGCATGCCTTGTGAGG 3'and 5'GTCGCCTTTTCCTGCTCTTCCCGC 3'and the restriction enzyme was BstUI; the digestion revealed the fragments of 223 and $23 \mathrm{bp}$ for $\mathrm{C}$ allele and $246 \mathrm{bp}$ for the $\mathrm{T}$ allele.

PCR program for IL-13 (-1512A/C and $-1112 \mathrm{C} / \mathrm{T})$ was applied under the following conditions: Initial denaturation at $94^{\circ} \mathrm{C}, 12 \mathrm{~min}$; followed by 35 cycles of denaturation at $95^{\circ} \mathrm{C}, 30 \mathrm{~s}$; annealing for $2 \mathrm{~min}$ at $65^{\circ} \mathrm{C}$ for IL-13 (-1512A/C); $54^{\circ} \mathrm{C}$ for IL-13 $(-1112 \mathrm{C} / \mathrm{T})$ and extension at $72{ }^{\circ} \mathrm{C}$ for $40 \mathrm{~s}$ followed by a final extension step at $72{ }^{\circ} \mathrm{C}$ for $5 \mathrm{~min}$ [27]. PCR products were 
separated on $2 \%$ agarose gel contained $0.5 \mu \mathrm{g} / \mathrm{mL}$ SYBR Safe and photographed under UV light.

\section{Determination of cytokine levels}

Three milliliter of peripheral venous blood sample taken from all patients and control groups. The blood samples were centrifuged at $3000 \mathrm{rpm}$ for $7 \mathrm{~min}$; the sera were stored at $-80^{\circ} \mathrm{C}$ until assayed.

Serum cytokine levels (IL-12, IL-13, TNF- $\alpha$ ) were analyzed by commercially available ELISA kits (InvitrogenThermo Fisher Scientific, Vienna, Austria) according to the manufacturer's instructions.

Table 1 Association analysis of TNF-a, IL-12 and IL-13 gene polymorphisms and brucellosis

\begin{tabular}{|c|c|c|c|c|c|c|}
\hline SNP & Model & Genotype & Patients no (\%) & Controls no (\%) & OR $(95 \% \mathrm{Cl})$ & P-value \\
\hline \multirow[t]{5}{*}{ TNF-a $(-238 \mathrm{G} / \mathrm{A})$} & & $\mathrm{G} / \mathrm{G}$ & $10(9.3)$ & $13(12.2)$ & 1.00 & 0.51 \\
\hline & & $A / G$ & $97(90.7)$ & $94(87.8)$ & $0.75(0.31-1.78)$ & \\
\hline & & $\mathrm{A} / \mathrm{A}$ & 0 & 0 & - & \\
\hline & Allele & A & $97(45)$ & $120(56)$ & $0.927(0.633-1.358)$ & 0.697 \\
\hline & & G & $117(55)$ & $94(44)$ & & \\
\hline \multirow[t]{11}{*}{ IL-12 (+1188 A/C) } & Codominant & $\mathrm{C} / \mathrm{C}$ & $22(20.6)$ & $29(27.1)$ & 1.00 & 0.19 \\
\hline & & $\mathrm{A} / \mathrm{C}$ & $78(72.9)$ & $66(61.7)$ & $0.64(0.34-1.22)$ & \\
\hline & & $\mathrm{A} / \mathrm{A}$ & $7(6.5)$ & $12(11.2)$ & $1.30(0.44-3.85)$ & \\
\hline & Dominant & $\mathrm{C} / \mathrm{C}$ & $22(20.6)$ & $29(27.1)$ & 1.00 & 0.26 \\
\hline & & $\mathrm{A} / \mathrm{C}-\mathrm{A} / \mathrm{A}$ & $85(79.4)$ & $78(72.9)$ & $0.70(0.37-1.31)$ & \\
\hline & Recessive & $\mathrm{C} / \mathrm{C}-\mathrm{A} / \mathrm{C}$ & $100(93.5)$ & $95(88.8)$ & 1.00 & 0.23 \\
\hline & & $\mathrm{A} / \mathrm{A}$ & $7(6.5)$ & $12(11.2)$ & $1.80(0.68-4.78)$ & \\
\hline & Overdominant & $\mathrm{C} / \mathrm{C}-\mathrm{A} / \mathrm{A}$ & $29(27.1)$ & $41(38.3)$ & 1.00 & 0.08 \\
\hline & & $\mathrm{A} / \mathrm{C}$ & $78(72.9)$ & $66(61.7)$ & $0.60(0.34-1.07)$ & \\
\hline & Allele & A & $126(59)$ & $112(52)$ & $0.962(0.656-1.412)$ & 0.845 \\
\hline & & $C$ & $88(41)$ & $102(48)$ & & \\
\hline \multirow[t]{11}{*}{ IL-13 (-1112C/T) } & Codominant & $T / T$ & $22(20.6)$ & $12(11.2)$ & 1.00 & 0.15 \\
\hline & & $C / T$ & $80(74.8)$ & $91(85)$ & $2.09(0.97-4.48)$ & \\
\hline & & $\mathrm{C} / \mathrm{C}$ & $5(4.7)$ & $4(3.7)$ & $1.47(0.33-6.52)$ & \\
\hline & Dominant & $\mathrm{T} / \mathrm{T}$ & $22(20.6)$ & $12(11.2)$ & 1.00 & 0.06 \\
\hline & & $\mathrm{C} / \mathrm{T}-\mathrm{C} / \mathrm{C}$ & $85(79.4)$ & $95(88.8)$ & $2.05(0.96-4.39)$ & \\
\hline & Recessive & $\mathrm{T} / \mathrm{T}-\mathrm{C} / \mathrm{T}$ & $102(95.3)$ & $103(96.3)$ & 1.00 & 0.73 \\
\hline & & $\mathrm{C} / \mathrm{C}$ & $5(4.7)$ & $4(3.7)$ & $2.05(0.96-4.39)$ & \\
\hline & Overdominant & $\mathrm{T} / \mathrm{T}-\mathrm{C} / \mathrm{C}$ & $27(25.2)$ & $16(14.9)$ & 1.00 & 0.059 \\
\hline & & $C / T$ & $80(74.8)$ & $91(85)$ & $1.92(0.97-3.82)$ & \\
\hline & Allele & $\mathrm{T}$ & $124(58)$ & $115(54)$ & $1.186(0.810-1.738)$ & 0.381 \\
\hline & & C & $90(42)$ & $99(46)$ & & \\
\hline \multirow[t]{11}{*}{ IL-13 (-1512A/C) } & Codominant & $A / A$ & $23(21.5)$ & $12(11.2)$ & 1.00 & 0.094 \\
\hline & & $\mathrm{A} / \mathrm{C}$ & $80(74.8)$ & $88(82.2)$ & $2.11(0.99-4.51)$ & \\
\hline & & $\mathrm{C} / \mathrm{C}$ & $4(3.7)$ & $7(6.5)$ & 3.35 (0.82-13.78) & \\
\hline & Dominant & $\mathrm{A} / \mathrm{A}$ & $23(21.5)$ & $12(11.2)$ & 1.00 & 0.041 \\
\hline & & $\mathrm{A} / \mathrm{C}-\mathrm{C} / \mathrm{C}$ & $84(78.5)$ & $95(88.8)$ & $2.17(1.02-4.62)$ & \\
\hline & Recessive & $\mathrm{A} / \mathrm{A}-\mathrm{A} / \mathrm{C}$ & $103(96.3)$ & $100(93.5)$ & 1.00 & 0.35 \\
\hline & & $\mathrm{C} / \mathrm{C}$ & $4(3.7)$ & $7(6.5)$ & $1.80(0.51-6.35)$ & \\
\hline & Overdominant & $\mathrm{A} / \mathrm{A}-\mathrm{C} / \mathrm{C}$ & $27(25.2)$ & $19(17.8)$ & 1.00 & 0.18 \\
\hline & & $\mathrm{A} / \mathrm{C}$ & $80(74.8)$ & $88(82.2)$ & $1.56(0.81-3.03)$ & \\
\hline & Allele & $A$ & $126(59)$ & $112(52)$ & $0.767(0.523-1.124)$ & 0.174 \\
\hline & & C & $88(42)$ & $102(48)$ & & \\
\hline
\end{tabular}




\section{Statistical analysis}

An online program, SNPSTats (http://bioinfo.iconcologia.net/ SNPstats) was used to calculate the genotype frequencies, Hardy Weinberg Equilibrium (HWE) and odds ratios. Version 16 of SPSS was used for analysing the data. $p$ value less than 0.05 was considered to be statistically significant.

\section{Results}

Table 1 shows the genotype and alleles of study participants. IL-13 (-1512 A/C) was associated with brucellosis risk in dominant model (OR $(95 \% \mathrm{CI})=$ 2.17 (1.02-4.62)), $P=0.041)$. Allele and genotype frequencies of IL12 (+1188 A/C), IL-13 (-1112 C/T), IL-13 (-1512 A/C) and TNF- $\alpha(-238 \mathrm{G} / \mathrm{A})$ were not significantly different between patients and controls. The serum levels of IL-12, TNF- $\alpha$ and IL-13 in patients with brucellosis and in controls are shown in Table 2 .

Serum level of IL-12 were $4.39 \pm 4.77 \mathrm{pg} / \mathrm{ml}$ and $2.68 \pm 2.02$ in brucellosis and control groups, respectively, which shown a significant difference $(p<0.001)$. The mean serum TNF- $\alpha$ level of patients with brucellosis $(15.20 \pm 60.37 \mathrm{pg} / \mathrm{ml})$ compared with the controls groups $(1.34 \pm 1.41 \mathrm{pg} / \mathrm{ml})$. This difference was statistically significant $(p<0.001)$. Serum levels of IL-13 were $(4.23 \pm 13.95,2.30 \pm 1.62) \mathrm{pg} / \mathrm{ml}$ in brucellosis and controls, respectively. As shown in Table 3, no significant associations were found between serum levels of IL-13, TNF- $\alpha$ and IL-12 and gene polymorphisms [TNF- $\alpha$ ($238 \mathrm{G} / \mathrm{A})$, IL-12 (+ $1188 \mathrm{~A} / \mathrm{C})$, IL-13 (-1112C/T) and IL-13 (-1512A/C)] in patients with brucellosis and controls. The AA, AC and CC genotype at positions IL-13 $(-1512 \mathrm{~A} / \mathrm{C})$ and IL-12 (+ $1188 \mathrm{~A} / \mathrm{C})$ showed a higher IL-13 and IL-12 serum levels in the case group than the control group. The AG and GG genotype at position TNF- $\alpha$ (-238 G/A) demonstrated a higher TNF- $\alpha$ serum level in patient group than the control group. The patient group with IL-13(-1112 C/T) CC, CT and TT genotypes had higher IL-13 serum level than that of the control group.

The results shown that serum levels of IL-13 (-1512A/ C), IL-13 (- $1112 \mathrm{C} / \mathrm{T})$, TNF- $\alpha(-238 \mathrm{G} / \mathrm{A})$ and IL-12 (+ $1188 \mathrm{~A} / \mathrm{C})$, were higher in all genotypes of patients than in the control group. However, the serum level of

Table 2 Serum levels of TNF-a, IL-12 and IL-13 in patients with brucellosis and controls

\begin{tabular}{llll}
\hline Interleukin $(\mathrm{pg} / \mathrm{ml})$ & $\begin{array}{l}\text { Patients } \\
\text { Mean } \pm \text { SD }\end{array}$ & $\begin{array}{l}\text { Controls } \\
\text { Mean } \pm \text { SD }\end{array}$ & $p$-value \\
\hline TNF-a & $15.20 \pm 60.37$ & $1.34 \pm 1.41$ & $<0.001$ \\
IL-12 & $4.39 \pm 4.77$ & $2.68 \pm 2.02$ & $<0.001$ \\
IL-13 & $4.23 \pm 13.95$ & $2.30 \pm 1.62$ & $<0.308$ \\
\hline
\end{tabular}

TNF- $\alpha(-238 \mathrm{G} / \mathrm{A})$ genotype AG and serum level of IL$12(+1188 \mathrm{~A} / \mathrm{C})$ genotypes $\mathrm{CC}$ and $\mathrm{AC}$ were significantly $(p$-value $<0.05)$ higher in patients with control groups (Table 3 ). Besides, there were significant association of IL-12 (+ $1188 \mathrm{~A} / \mathrm{C})$, TNF- $\alpha$ (-238 G/A) and IL$13(-1512 \mathrm{~A} / \mathrm{C})$ polymorphisms with the serum levels of these cytokines in both patient and healthy groups separately.

\section{Discussion}

Numerous factors including immunity, environment, and genetics affect the susceptibility to infectious diseases. Studies have shown that single nucleotide polymorphism in genes can influence the regulation of immune responses. The aim of this study was to investigate the probable relationship between TNF$\alpha)-238 \mathrm{G} / \mathrm{A}), \mathrm{IL}-12$ (+1188 A/C), and IL-13 (- 1512 $\mathrm{A} / \mathrm{C}$ and $-1112 \mathrm{C} / \mathrm{T}$ ) gene polymorphisms and their serum concentrations and susceptibility to Brucella infection.

Our results showed that there was no significant association between the genotypes or alleles of IL-13 (- $1112 \mathrm{C} / \mathrm{T})$, IL-13 (-1512 A/C), IL12 (+ $1188 \mathrm{~A} / \mathrm{C})$ and TNF- $\alpha$ ) - 238 G/A) between patients with brucellosis and the control group, although the dominant model of IL-13 (-1512 A/C) influence the susceptibility to brucellosis ( $p$ value: 0.041). The previous study have reported significant differences between patients with brucellosis and controls in GG/GG genotypes of TNF- $\alpha(-238 \mathrm{G} / \mathrm{A},-308 \mathrm{G} / \mathrm{A})$ and $\mathrm{G}$ allele of TNF- $\alpha$ (-238 G/A) locations [28]. According to study by Eskandari-Nasab et al. GG genotype at position (-308 G/A) was higher in the control group than in the patients and this genotype was a protective factor while GA genotype, A allele, AAG haplotype were a risk factor against developing brucellosis [29]. Caballero et al. from Spain has shown that TNF-a (-308) polymorphisms influence the susceptibility to brucellosis [15].

Studies on Interleukin 12 shown that the frequencies of IL-12 AA genotype and A allele were higher in controls than in patients $[30,31]$. Previous studies suggested that IL-12 (+1188) was related to the susceptibility or resistance to brucellosis and tuberculosis [32, 33]. An additional study found no influence of IL-13 polymorphisms on brucellosis infection [34]. Cytokines play a key role in the regulation of the immune responses [35-37]. In the present study, patients had significantly elevated serum levels of IL-12 and TNF- $\alpha$ compared to healthy controls. In terms of IL13 levels, no significant difference was found between patient and control groups. In accordance with our results, Sanaei Dashti et al. observed that TNF- $\alpha$ and IL-12 serum levels were elevated significantly in 
Table 3 Serum levels of TNF-a, IL-12 and IL-13 in brucellosis patients and control groups with different genotypes

\begin{tabular}{|c|c|c|c|c|c|c|}
\hline \multirow{2}{*}{$\begin{array}{l}\text { SNPS } \\
\text { IL-13 (-1512A/C) }\end{array}$} & \multirow[t]{2}{*}{ Groups/Genotypes } & \multicolumn{4}{|c|}{ Serum levels } & \multirow{2}{*}{$\frac{p-\text { value }^{b}}{0.07}$} \\
\hline & & \multicolumn{4}{|c|}{ Serum IL-13 levels (pg/ml) } & \\
\hline & Genotypes & AA & $A C$ & CC & $p$-value ${ }^{a}$ & \\
\hline & Case $(n=107)$ & $2.29 \pm 2.31$ & $4.87 \pm 16.06$ & $2.47 \pm 0.60$ & $<0.001$ & \\
\hline & Control $(n=107)$ & $1.89 \pm 1.28$ & $2.41 \pm 1.68$ & $1.62 \pm 1.14$ & $<0.001$ & \\
\hline & $p$-value ${ }^{c}$ & 0.58 & 0.16 & 0.21 & & \\
\hline \multirow[t]{4}{*}{ IL-13(-1112 C/T) } & Genotypes & $\mathrm{CC}$ & $C T$ & $\pi$ & & 0.187 \\
\hline & Case $(n=107)$ & $2.47 \pm 1.62$ & $4.59 \pm 16.06$ & $3.29 \pm 3.08$ & $<0.001$ & \\
\hline & Control $(n=107)$ & $1.82 \pm 1.27$ & $2.34 \pm 1.66$ & $2.21 \pm 1.46$ & $<0.001$ & \\
\hline & $p$-value ${ }^{c}$ & 0.24 & 0.19 & 0.26 & & \\
\hline \multirow[t]{5}{*}{ TNF-a $(-238 \mathrm{G} / \mathrm{A})$} & & \multicolumn{3}{|c|}{ Serum TNF-a levels (pg/ml) } & & 0.718 \\
\hline & Genotypes & AA & $A G$ & GG & & \\
\hline & Case $(n=107)$ & - & $15.71 \pm 63.22$ & $10.22 \pm 16.50$ & $<0.001$ & \\
\hline & Control $(n=107)$ & - & $1.28 \pm 1.39$ & $1.72 \pm 1.54$ & $<0.001$ & \\
\hline & $p$-value ${ }^{c}$ & - & 0.02 & 0.07 & & \\
\hline \multirow[t]{5}{*}{ IL-12 (+1188 A/C) } & & \multicolumn{3}{|c|}{ Serum IL-12 levels (pg/ml) } & & 0.172 \\
\hline & Genotypes & AA & $A C$ & $\mathrm{CC}$ & & \\
\hline & Case $(n=107)$ & $2.71 \pm 1.69$ & $4.85 \pm 5.47$ & $3.28 \pm 1.20$ & $<0.001$ & \\
\hline & Control $(n=107)$ & $2.60 \pm 1.67$ & $2.70 \pm 2.10$ & $2.66 \pm 2.03$ & $<0.001$ & \\
\hline & $p$-value ${ }^{c}$ & 0.89 & 0.003 & 0.02 & & \\
\hline
\end{tabular}

${ }^{a} p$-value was calculated based on one-sample Chi-square test, the genotypes frequencies were compared in case and control separately

${ }^{\mathrm{b}} p$-value was calculated based on Chi-square test in a contingency table

c $p$-value was calculated based on independent t-test/Mann-Whitney test

brucellosis patients compared to the levels in other febrile patients [38]. In addition, the results of Demirdag and colleagues showed that serum level of TNF- $\alpha$ was high in patients than in controls and reported that this cytokines involved in the pathophysiology of brucellosis [39]. Another study reported that serum level of IL-12 in acute and chronic brucellosis patients were significantly higher than control group [40]. In contrast to our study, Ahmed et al. demonstrated serum level of TNF- $\alpha$ was not detectable in all the serum samples collected from patients; while high serum levels of IL-12 in the patient group compared to the control and patients without brucellosis groups was reported [41]. In our study, no significant associations were found between serum levels of IL-13, TNF- $\alpha$ and IL-12 and different genotypes [TNF- $\alpha(-238$ G/A), IL$12(+1188 \mathrm{~A} / \mathrm{C}), \mathrm{IL}-13(-1112 \mathrm{C} / \mathrm{T}$ and IL-13-1512A/ C)] of the brucellosis patients and controls.

We did not find any study of association between polymorphism IL-13 (-1512 A/C) and infectious diseases in the literature except for brucellosis [34], although the polymorphism of IL-13 $(-1112 \mathrm{C} / \mathrm{T})$ has been shown to be associated with susceptibility to periodontitis [42]. There were no studies about association between serum levels of these cytokines and gene polymorphisms in brucellosis.

\section{Conclusions}

The IL-13 gene polymorphism can be used as a biomarker for detecting susceptibility to brucella disease. Further studies with higher sample size in different populations and the effect of response to treatment on cytokine concentrations should be considered.

\section{Abbreviations}

ARMS: Amplification refractory mutation system; ELISA: Enzyme-linked immunosorbent assay; IFN-ү: Interferon gamma; IL: Interleukin; PCR: Polymerase chain reaction; RFLP: Restricted fragment length polymorphism; TNF-a: Tumor necrosis factor alpha

\section{Acknowledgments}

The authors would like to acknowledge Vice-chancellor of Research and Technology, Hamadan University of Medical Sciences, Hamadan, Iran, and microbiology laboratory staffs.

\section{Authors' contributions}

MYA designed and supervised the study. MS and MAH performed data interpretation. SK was responsible for data collection and doing experiments. FK and SHH performed clinical examination and interpreted the results. ARS analyzing the statistical results of the study. AVR interpretation of data. All authors read and approved the final manuscript.

\section{Funding}

The Vice-chancellor of Research and Technology, Hamadan University of Medical Sciences, Hamadan, Iran supported financially the study (Grant Number: 9604272614). The funding body had no role in the design of the study and collection, analysis, and interpretation of data and in writing the manuscript. 


\section{Availability of data and materials}

The datasets used and/or analyzed during the current study available from the corresponding author on reasonable request.

\section{Ethics approval and consent to participate}

The ethics committee of the Hamadan University of Medical Sciences approved the study protocol (Ethical approval code: IR.UMSHA.REC.1396.157). Ethical Review Board approved written consent taken from all the participants.

\section{Consent for publication}

Not applicable.

\section{Competing interests}

The authors declare that they have no competing interests.

\section{Author details}

'Department of Microbiology, School of Medicine, Hamadan University of Medical Sciences, Hamadan, Iran. ${ }^{2}$ Department of Clinical Biochemistry, School of Medicine, Kermanshah University of Medical Sciences, Kermanshah, Iran. ${ }^{3}$ Brucellosis Research Center, Hamadan University of Medical Sciences, Hamadan, Iran. ${ }^{4}$ Research Center for Molecular Medicine, Hamadan University of Medical Sciences, Hamadan, Iran. ${ }^{5}$ Department of Biostatistics and Epidemiology, School of Public Health, Hamadan University of Medical Sciences, Hamadan, Iran. ${ }^{6}$ Department of Immunology, Hamadan University of Medical Sciences, Hamadan, Iran.

Received: 6 August 2019 Accepted: 29 November 2019 Published online: 09 December 2019

\section{References}

1. Corbel MJ. Brucellosis: an overview. Emerg Infect Dis. 1997;3:213-21.

2. Arroyo Carrera I, Lopez Rodriguez MJ, Sapina AM, Lopez Lafuente A, Sacristan AR. Probable transmission of brucellosis by breast milk. J Trop Pediatr. 2006:52:380-1.

3. Kato Y, Masuda G, Itoda I, Imamura A, Ajisawa A, Negishi M. Brucellosis in a returned traveler and his wife: probable person-to-person transmission of Brucella melitensis. J Travel Med. 2007;14:343-5.

4. Franco MP, Mulder M, Gilman RH, Smits HL. Human brucellosis. Lancet Infect Dis. 2007;7:775-86

5. Young EJ. An overview of human brucellosis. Clin Infect Dis. 1995;21:283-9 quiz 90.

6. Acha NP, Szyfres B. Zoonoses and communicable diseases common to man and animals, vol. 1. 3rd ed. Washington D. C.: Pan American Health Organization (PAHO); 2003

7. Megid J, Mathias LA, Robles C. Clinical manifestations of brucellosis in domestic animals and humans. Open Vet Sci J. 2010;4:119-26.

8. Lucero NE, Ayala SM, Escobar Gl, Jacob NR. Brucella isolated in humans and animals in Latin America from 1968 to 2006. Epidemiol Infect. 2008;136:496-503.

9. Pappas G, Papadimitriou P, Akritidis N, Christou L, Tsianos EV. The new global map of human brucellosis. Lancet Infect Dis. 2006;6:91-9.

10. Hashemi SH, Keramat F, Ranjbar M, Mamani M, Farzam A, Jamal-Omidi S Osteoarticular complications of brucellosis in Hamedan, an endemic area in the west of Iran. Int J Infect Dis. 2007:11:496-500.

11. Karaoglan I, Pehlivan S, Namiduru M, Pehlivan M, Kilincarslan C, Balkan Y, et al. TNF-alpha, TGF-beta, IL-10, IL-6 and IFN-gamma gene polymorphisms as risk factors for brucellosis. New Microbiol. 2009;32:173-8.

12. Zhan Y, Kelso A, Cheers C. Differential activation of Brucella-reactive CD4+ T cells by Brucella infection or immunization with antigenic extracts. Infect Immun. 1995;63:969-75.

13. Huang L-Y, Aliberti J, Leifer CA, Segal DM, Sher A, Golenbock DT, et al. Heatkilled Brucella abortus induces TNF and IL-12p40 by distinct MyD88dependent pathways: TNF, unlike IL-12p40 secretion, is Toll-like receptor 2 dependent. J Immunol. 2003;171:1441-6.

14. Sathiyaseelan J, Goenka R, Parent M, Benson RM, Murphy EA, Fernandes DM, et al. Treatment of Brucella-susceptible mice with IL-12 increases primary and secondary immunity. Cell Immunol. 2006;243:1-9.

15. Caballero A, Bravo MJ, Nieto A, Colmenero JD, Alonso A, Martin J. TNFA promoter polymorphism and susceptibility to brucellosis. J Clin Exp Immunol. 2000a;121:480-3.
16. Cooper AM, Magram J, Ferrante J, Orme IM. Interleukin 12 (IL-12) is crucial to the development of protective immunity in mice intravenously infected with mycobacterium tuberculosis. J Exp Med. 1997;186:39-45.

17. LOH HSIU YIN A. Association studies of genetic polymorphisms found in interleukins 12, 13 and CD14 gene with asthma and allergic diseases 2005.

18. Bergholdt R, Ghandil P, Johannesen J, Kristiansen O, Kockum I, Luthman H, et al. Genetic and functional evaluation of an interleukin-12 polymorphism (IDDM18) in families with type 1 diabetes. J Med Genet. 2004;41:e39.

19. Jang J-P, Cho W-K, Baek I-C, Choi E-J, Shin D-H, Suh B-K, et al. Comprehensive analysis of cytokine gene polymorphisms defines the association of IL-12 gene with ophthalmopthy in Korean children with autoimmune thyroid disease. Mol Cell Endocrinol. 2016;426:43-9.

20. Loures MAR, Alves HV, de Moraes AG, Santos TDS, Lara FF, JSF N, et al, Association of TNF, IL12, and IL23 gene polymorphisms and psoriatic arthritis: meta-analysis. Expert Rev Clin Immunol. 2019;15:1-11.

21. Reichert S, Machulla HK, Klapproth J, Zimmermann U, Reichert Y, Gläser C, et al. Interferon-gamma and interleukin-12 gene polymorphisms and their relation to aggressive and chronic periodontitis and key periodontal pathogens. J Periodontal. 2008;79:1434-43.

22. Santos AC, de Moura EL, Ferreira JM, Santos BR, Alves VM, de Farias KF, et al. Metaanalysis of the relationship between TNF-a $(-308 \mathrm{G} / \mathrm{A})$ and IL-10 (-819C/T) gene polymorphisms and susceptibility to dengue. Immunol Investig. 2017;46:201-20.

23. Hollegaard M, Bidwell J. Cytokine gene polymorphism in human disease: on-line databases, supplement 3. Genes Immun. 2006;7:269.

24. Kazemi S, Saidijam M, Hashemi SH, Karami M, Vaisi-Raygani A, Alikhani MY. Analysis of IL-10 and IL-6 gene polymorphisms and their serum levels in patients with brucellosis: a case control study. Immunol Investig. 2016;45:107-15.

25. Sen A, Paine SK, Chowdhury $H_{H}$, Mondal LK, Mukherjee A, Biswas A, et al. Association of interferon-gamma, interleukin-10, and tumor necrosis factoralpha gene polymorphisms with occurrence and severity of Eales' disease. Invest Ophthalmol Vis Sci. 2011;52:171-8.

26. Thada S, Ponnana M, Sivangala R, Joshi L, Alasandagutti M, Ansari MS, et al. Polymorphisms of IFN-gamma (+874A/T) and IL-12 (+1188A/C) in tuberculosis patients and their household contacts in Hyderabad, India. Hum Immunol. 2016a;77:559-65.

27. Kim HB, Kang MJ, Lee SY, Jin HS, Kim JH, Kim BS, et al. Combined effect of tumour necrosis factor-alpha and interleukin-13 polymorphisms on bronchial hyperresponsiveness in Korean children with asthma. Clin Exp Allergy. 2008;38:774-80.

28. Davoudi S, Amirzargar AA, Hajiabdolbaghi M, Rasoolinejad M, Soodbakhsh A, Jafari $S$, et al. Th-1 cytokines gene polymorphism in human brucellosis. Int J Immunogenet. 2006;33:355-9.

29. Eskandari-Nasab E, Moghadampour M, Sepanj-Nia A. TNF-alpha $-238,-308,-863$ polymorphisms, and brucellosis infection. Hum Immunol. 2016;77:121-5.

30. Kamali-Sarvestani E, Rasouli M, Mortazavi H, Gharesi-Fard B. Cytokine gene polymorphisms and susceptibility to cutaneous leishmaniasis in Iranian patients. Cytokine. 2006;35:159-65.

31. Rasouli M, Kiany S, Moravej A, Kalani M. Interleukin-12 and tumor necrosis factor- $\beta$ gene polymorphisms as genetic susceptibility factors for brucellosis in Iranian patients. Iran Red Crescent Med J. 2010;12:266.

32. Kabiri F, Rajabnia R, Pournajaf A, Gholami M, Bibalan MH, Kassani A, et al. Association between cytokine gene polymorphisms and human susceptibility to brucellosis. Arch Pediatr Infect Dis. 2017;5(3):e57274. https:// doi.org/10.5812/pedinfect.57274.

33. Thada S, Ponnana M, Sivangala R, Joshi L, Alasandagutti M, Ansari MSS, et al. Polymorphisms of IFN- $\gamma(+874 \mathrm{~A} / \mathrm{T})$ and IL-12 (+ 1188A/C) in tuberculosis patients and their household contacts in Hyderabad, India. Hum Immunol. 2016b;77:559-65.

34. Sayed-Jalal-Aladin A-M, Rasouli M, Najafipour S, Moravej A, Kalani M, Negahdaripour M. Relation between interleukin-13 gene polymorphisms and susceptibility to brucellosis in Iranian population. Trends Pharmacol Sci. 2016;2:17-24

35. Fernandes DM, Jiang $X$, Jung $J H$, Baldwin CL. Comparison of $T$ cell cytokines in resistant and susceptible mice infected with virulent Brucella abortus strain 2308. FEMS Immunol Med Microbiol. 1996;16:193-203.

36. Jiang X, Baldwin CL. Effects of cytokines on intracellular growth of Brucella abortus. Infect Immun. 1993;61:124-34.

37. Zhan Y, Kelso A, Cheers C. Cytokine production in the murine response to brucella infection or immunization with antigenic extracts. Immunol. 1993;80:458.

38. Dashti AS, Karimi A, Elyasi B, Shamshiri AR, Shoja SA, Shamshiri M. Cytokine profiles in acute brucellosis, compared with those in other febrile illnesses. 
Arch Clin Infect Dis. 2017;12(4):e66077. https://doi.org/10.5812/archcid. 66077.

39. Demirdag K, Ozden M, Kalkan A, Godekmerdan A, Kilic SS. Serum cytokine levels in patients with acute brucellosis and their relation to the traditional inflammatory markers. FEMS Immunol Med Microbiol. 2003;39:149-53.

40. Rezaee MA, Jalili A, Motaharinia Y, Mohsenpour B, Hakhamaneshi M, Rashidi A, et al. Cytokines' level in acute and chronic brucellosis patients. Horiz Med Sci. 2012;18:115-20.

41. Ahmed K, Al-Matrouk KA, Martinez G, Oishi K, Rotimi VO, Nagatake T. Increased serum levels of interferon-gamma and interleukin-12 during human brucellosis. Am J Trop Med Hyg. 1999;61:425-7.

42. Zhang W, XU P, Chen Z, Cheng Y, Li X, Mao Q. IL-13 -1112 polymorphism and periodontitis susceptibility: a meta-analysis. BMC Oral Health. 2018;18:21.

\section{Publisher's Note}

Springer Nature remains neutral with regard to jurisdictional claims in published maps and institutional affiliations.

Ready to submit your research? Choose BMC and benefit from:

- fast, convenient online submission

- thorough peer review by experienced researchers in your field

- rapid publication on acceptance

- support for research data, including large and complex data types

- gold Open Access which fosters wider collaboration and increased citations

- maximum visibility for your research: over $100 \mathrm{M}$ website views per year

At BMC, research is always in progress.

Learn more biomedcentral.com/submissions 